\title{
Seeing Farmers' Markets: Theoretical and Media Perspectives on New Sites of Exchange in New Zealand
}

\author{
LEX CHALMERS $^{1 *}$, ALUN E. JOSEPH ${ }^{2}$ and JOHN SMITHERS ${ }^{2}$ \\ ${ }^{1}$ Department of Geography, University of Waikato, P O Box 3105, Hamilton New Zealand \\ ${ }^{2}$ Department of Geography, University of Guelph, Ontario, Canada N1G 2WI \\ *Corresponding author. Email: lex@waikato.ac.nz
}

Received 24 April 2007; Revised 30 August 2007; Accepted 2 February 2009

\begin{abstract}
In this paper we explore the extent to which a reciprocal relationship exists between contemporary theorisation about farmers' markets in geography and the rapidly expanding public discourse surrounding these sites of exchange in New Zealand. Activities branded as farmers' markets are seen widely as local phenomena of systemic significance for the understanding of evolving geographies of production, consumption and exchange. As something 'new' on the landscape, farmers' markets also attract attention in the media. An electronic database of significant print media contributions over the period 1995 to 2007 provides the empirical basis for an assessment of the extent to which theorisation and the public discourse address common themes. Our analysis indicates that, while the economic and social constructions in both the research literature and the media database share common themes, strong contrasts in ways of 'seeing' farmers' markets are apparent. We note the predilection in the print media to present the nature and purpose of farmers' markets through the personal experiences and 'stories' of participants. There is a tendency to focus on the appeal of markets to the consumers who form the readership base. The theorised alterity of the farmers' market, either in terms of production methods or motivations for consumption, is not reflected strongly in media reports, and this raises questions about 'over-theorisation' in the academic literature. Our aim is to promote reflection in both the editorial offices of the media and in the academy by documenting the nature of these contrasting views.
\end{abstract}

KEY WORDS New Zealand; rural; local food systems; enterprise; consumption landscapes; Newztext

\section{Introduction}

Amidst mounting public interest in the geographic origins and ecological 'footprint' of food, increasing attention has been given to so-called alternative or local food systems. For some, these systems imply distinctive production practices such as biodynamic or organic farming, but for others it is the re-casting of exchange, both social and economic, between food pro- ducers and consumers that is critical (Connell, et al., 2008). Our interest is in Farmers' Markets, defined as '... specialist markets trading in "locally produced" products, focussing largely on food... which is either locally grown or incorporates locally grown ingredients' (Holloway and Kneafsey, 2000, 286). Farmers' Markets are arguably the most visible and intuitively obvious staging ground for trade in differentiated 
food products of local provenance; they are places in which the diverse goals and values of food producers and consumers are thought to find expression through both commerce and communication (Feagan, et al., 2004; Holloway and Kneafsey, 2000).

Markets for agricultural produce have been a feature of rural and urban settlements for centuries, but the branding, social elevation and commercial promotion associated with contemporary Farmers' Markets is a relatively new feature in North America (Feagan et al., 2004), Britain (Kneafsey and Ilbery, 2001), Australia (Coster, 2004) and New Zealand (Guthrie et al., 2006). Not surprisingly, this expansion and repositioning of Farmers' Markets has caught the attention of academics interested in understanding and theorising about the dynamics of rural change as they relate to new patterns of production and consumption (Hinrichs, 2003; Kirwan, 2004). Somewhat less expected, perhaps, is the amount of coverage and commentary devoted to Farmers' Markets by the media. It appears that Farmers' Markets are an economic innovation and a social 'happening' that have captured sufficient public interest to warrant their inclusion in the press - a press that has the capacity to both report and shape the way in which this innovation is operated, understood and 'consumed'.

In this paper we focus on the Farmers' Market experience in New Zealand, where the phenomenon has emerged only recently and is still visibly 'under construction' in its form and function. We suggest that media interest flows from the very newness of Farmers' Markets as a food marketing venture, with the first markets emerging in Whangarei and Hawke's Bay roughly a decade ago, and the rapid creation of more than 20 markets across the country (Australian Farmers' Markets Association/Farmers' Markets New Zealand, 2007). However, we also believe that media interest, and by implication that of the reading public, reflects the breadth of the appeal of this new site of exchange; the 'Farmers' Market story' is one that engages those interested in supporting local farmers, those concerned with the provenance and quality of food, and those seeking to enjoy a distinctive consumption experience.

The definition of Farmers' Markets supplied above is one of many normative characterisations that can be found in academic writing, policy statements and public discourse. Observation of the Farmers' Market experience internationally suggests that notions of the value, authenticity, and distinctiveness of Farmers' Markets are con- structed and codified in different ways and by different actors. While academic commentators communicate through the dissemination of ideas and findings in scholarly publications, the views and values of the public are largely shaped and reflected in the media. The media provides a rich and frequently under-utilised window on how ideas circulate and find expression in the actions of people. In this paper, we work with the international academic debate and with the media coverage of Farmers' Markets in New Zealand, focusing on the emergence of Farmers' Markets as new sites of exchange. We seek to champion neither the theoretical discourse nor the media coverage as means of 'seeing' Farmers' Markets, but to learn from them both. Specifically, we are interested in (i) how theoretical understandings and expectations are reflected in the public (media) coverage and (ii) the degree to which the media are promoting a particular understanding of Farmers' Markets as sites of exchange.

The paper is organised in three sections. First, we situate or 'problematise' Farmers' Markets as spaces of engagement in a changing, and increasingly consumption-oriented, rural landscape. In the process of mapping Farmers' Markets onto this theoretical landscape, a number of discrete issues are noted in the realms of production, consumption and exchange and these are used to frame the sequential deconstruction of media coverage of Farmers' Markets in a second major section. In a final section, the results of the media deconstruction are cast back against the generalised understanding of the role of Farmers' Markets, and tentative conclusions are drawn concerning their potential role in shaping the evolving relationship between farmers (as producers of food) and (largely urban-based) consumers.

\section{Placing the Farmers' Market in New Zealand}

A preliminary scan of the literature indicates that we might place the emergence of Farmers' Markets variously within a post-productivist rural landscape (Holloway and Kneafsey, 2000), a turn to 'quality' and to the 'local' in food consumption (Goodman, 2003; Hinrichs, 2000) and within the evolving dynamics of agriculturecommunity linkages (Kirwan, 2004; Smithers, et al., 2005). We choose the last of these perspectives; in part because we see in Farmers' Markets an emergent linkage of potential importance, but also because it does not preclude the inclusion of insights derived from the application of other 
perspectives. Following Joseph et al. (2001), we organise our interrogation of the theoretical literature with reference to the processes of production, consumption and exchange that lie at the core of an evolving rurality.

\section{Production: the view from agriculture}

Holloway and Kneafsey (2000, 297) place Farmers' Markets

... in a theoretically elegant, but empirically uncertain 'post-productivist countryside' in which ideas of food quality may be more significant than quantity of production, and where consumers are increasingly concerned with issues of food safety, food quality, and the association of their food with lifestyles....

We support the assertion that Farmers' Markets are connected with the turn to 'quality' and the growing ascendancy of lifestyle considerations in food purchasing decisions, but do not see these as necessarily embedded in a post-productivist countryside. Indeed, like Argent (2002) we see a poor fit between largely European notions of a post-productivist rurality and the continued dominance of much of the Antipodean landscape by large-scale productivist farms. Consequently, we view Farmers' Markets as an intriguing symptom of growing diversity within a landscape still dominated by traditional productivist values.

For present purposes, on the production side we note two areas of uncertainty and potential public interest that are amenable to investigation in the deconstruction of the media coverage. First, we seek to understand the place of 'local' farming and farmers in the framing of the Farmers' Market experience in New Zealand. We note that, in the academic literature, conceptions of local farming and local food are commonly associated with a set of preferred (and inferred) structural characteristics that do not include all local producers; namely that the scale of production is 'small' (read 'non-industrial') and that the methods of farming are quality assured with reference to their environmental, social and economic impacts. Yet, while the popular notion might be that these characteristics are inextricably linked such that each is, in effect, code for the other, advocates of the environmental performance of 'big agriculture' point to the widespread uptake of environmental schemes by large scale producers and the existence of rigorous food quality standards as evidence to the contrary
(Armitage, 2001; Seymore and Ridley, 2005). Regardless of farm size, the basic need for economic viability is abiding; producers will make choices that are not only rewarding but economically sustainable as well. Hence, from the producer side, there emerges the question of 'who will supply foods of local provenance in the alternative food system?'

A second, and highly significant, dimension of Farmers' Market food as it relates to production is the belief that it possesses qualities of 'otherness' in relation to what is on offer in a supermarket. For many consumers this relates to expectations about how the food was produced in other words, the production practices of the farmer. Prominent among these differentiated forms of farming and food production is organic agriculture. Indeed, organic farming and food are deeply embedded within academic discourses of local food (Connell et al., 2008: Goodman, 2002; McMichael, 2000). Analyses from the farm side have documented farmers' motivations for adopting organic production methods. These range from philosophical attitudes toward the environment, to beliefs concerning the safety and nutritional value of organic food, and the profitability of smaller holdings through reduced costs and premium product pricing (McEachern and Willock, 2004; Rigby and Caceres, 2001). Within the space of Farmers' Markets lies an assumed opportunity for organic (and related) producers to connect with a clientele that, if not uniform in its support for alternatively produced food, is at least weighted toward this preference. Hence, for many organic producers seeking support at Farmers' Markets, the question might be 'if not here, then where?' However, the basis for this support is unclear and amenable to investigation. For example, Allen et al. (2003, 62) question whether these alternative food initiatives are significantly oppositional or primarily alternative.

Deriving from the above, in our deconstruction of the media coverage of Farmers' Markets we assess (i) the frequency and type of emphasis placed on support for local producers, especially smaller ones, and (ii) the degree to which organic or other non-conventional production is valorised over and above local food.

\section{Consumption: the view from the community}

The turn to quality - the valorising of organic and 'local' production by consumers - can be seen as an important component of the emergence of alternative systems of food production 
(Goodman, 2002: Goodman and DuPuis, 2002: Ilbery and Kneafsey, 2000). At a broad cultural level, it can be seen as conservative, a yearning for a simpler and seemingly idyllic past. Bell (2006, 157) argues that '.. the demand for "fresh" food signals a desire to eat food closer to nature - or, more accurately, food presented to us as closer to nature'. In analysing this 'presentation' of food, Connell et al. (2008) note that '... the semantics of "good food" gets bundled into a "local food systems" package, wherein organic is good, family-scale farming is good, local is good, natural is good, and shopping at farmers' markets is good'. Of particular significance within the chain of reasoning embedded in the rhetoric of good food is the assumption on the part of consumers that quality and the local are related in some strong and significant way, such that local becomes a synonym for quality (Holloway and Kneafsey, 2000). What then, specifically, of the motivations for shopping at Farmers' Markets? Is the customer base dominated by 'concerned consumers' such as those identified by Weatherell et al. (2003) in the UK? Or is the situation more complex?

Miele (2006) challenges the hegemony of 'reflexive consumption' through which individuals define themselves through active engagement with the attributes of that which they chose to purchase (Kirwan, 2004). Instead, she suggests that the desire to buy organic and/or local food and to have a face-to-face relationship with producers may be less important for many visitors to Farmers' Markets than novelty and social atmosphere; '. . . markets survive by attracting a growing number of ordinary consumers interested in novelty, freshness, quality and in the opportunity for shopping with friends in a friendly atmosphere' (Miele, 2006, 351). In this sense, the Farmers' Market experience itself becomes a commodity to be enjoyed. Evidence from the UK supports the existence of reflexive consumption among at least a sub-set of visitors to Farmers' Markets (Holloway and Kneafsey, 2000: Kirwan, 2004), but evidence from the US and Canada is supportive of the presence of mixed and overlapping motivations (Feagan, et al., 2004). Drawing on a survey of Farmers' Market customers in British Columbia, Connell et al. (2008) point toward differences between regular and non-regular patrons of Farmers' Markets, with the former more interested in the recyclability of packaging, organic certification, shopping seasonally and buying locally. This suggests that, for relatively new Farmers'
Markets (i.e., all those in New Zealand), there may be a strong 'curiosity factor' motivating many first-time visitors. Feagan et al. (2004, 250) go further and warn that '. . . there is a need to be wary of the dangers of the commodification of the experience of the farmers' market by its patrons and to be wary of the over-pricing of niche market foods in a farmers' market situation - sometimes sardonically referred to as "yuppie chow".

Clearly, the consumption side of Farmers' Markets is characterised by diversity of purpose and considerable nuance in the meaning of 'good food' and 'distinctive experience'. In deconstructing the media coverage of Farmers' Markets, we assess (i) the emphasis placed on the quality of food, and the association of such quality with its localness, and (ii) the degree to which Farmers' Markets are portrayed and promoted as a commodity in their own right.

\section{Exchange: re-linking town and country?}

Farmers' Markets could be viewed as institutional structures that promote the re-linking of agriculture with the broader community through the re-placing of food production into its local milieu and the re-embedding of food purchases within community-based social relations. In examining Farmers' Markets for alterity ('otherness') with respect to the conventional agro-food system, Kirwan $(2004,411)$ warns against the assumption of absolutes:

Ostensibly, the local and social embeddedness of the exchange at Farmers' Markets ... is maximised when it is the actual producer selling their own selectively processed food to consumers who can directly relate to the place of production. However, in reality there is a degree of flexibility in the management of Farmers' Markets, such as extending the radius from which producers must come ... it would appear that there are few absolutes when it comes to defining this flexibility.

For example, Holloway and Kneafsey (2000) report that, when there are too many producers in a particular category, preference is given in the Stratford Farmers' Market to the 'most local'. Indeed, the way in which the importance and centrality of the participation of 'local' producers is conceived and controlled emerges as a notion amenable to empirical investigation, especially given the popular conception of Farmers' 
Markets as forums for communication and connection.

A second dimension of 'exchange' found in the literature pertains not to the interpersonal value of direct selling and buying, but rather to the belief that the re-spatialising of trade in food will produce benefits to agriculture and community alike - such that the sustainability of both sectors is enhanced. Such benefits are thought to flow from the lessening of economic leakages associated with imported food and the ability to achieve stronger (local) economic growth through the closer integration of production and consumption (Ilbery and Maye, 2005; Winter, 2003). Reflections of this dynamic lie in the capacity of Farmers' Markets to facilitate the de-coupling of producers from the so-called 'industrial food chain' (Andreatta and Wickliffe, 2002), in the desire of regions to build a stronger sense of geographical identity in the form of place-branding (Warner, 2007) or in a defensive posture that has the intent of promoting the local but (presumably unintended) effect of enforcing elitism and exclusion (Hinrichs et al., 2004).

As in the areas of production and consumption, the notion(s) of exchange are multidimensional and nuanced. In deconstructing the media coverage of Farmers' Markets as sites of exchange, we assess (i) the emphasis placed on the number and nature of local producers and the assumed benefits of food purchase from them, and (ii) the degree to which Farmers' Markets are portrayed and promoted as a part of agriculture and community (co)development.

\section{Seeing Farmers Markets: media descriptions and constructions}

The analysis reported below uses a database constructed from a digital data source, the Newztext Plus database (www.knowledge-basket.co.nz/ publibnewz/). Newztext Plus provides an on-line database of full text copy contributed by the publishers of New Zealand's major print media sources. Newztext Plus is an archive of New Zealand's key news and business publications, and it has grown to an average of 400,000 entries a year since 2000 . We acknowledge that some major publications fall outside the Newztext Plus system; The Listener, Insight Magazine and many community newspapers have carried significant commentaries on Farmers' Markets. However, the analytical advantages of a digital source are significant.

The Newztext Plus search engine allowed 'farmers' market' as the search term, and permit-
Table 1 Media reports on 'Farmers' Markets', 1996-2007.

\begin{tabular}{|c|c|}
\hline 1996 & 6 \\
\hline 1997 & 6 \\
\hline 1998 & 3 \\
\hline 1999 & 2 \\
\hline 2000 & 9 \\
\hline 2001 & 37 \\
\hline 2002 & 59 \\
\hline 2003 & 81 \\
\hline 2004 & 86 \\
\hline 2005 & 144 \\
\hline 2006 & 313 \\
\hline 2007 & $43 . .$. (January) \\
\hline
\end{tabular}

Source: Newstext Plus Database, accessed February, 2007.

ted controls to be placed on the media source and publication date. The database held nearly 800 items that had the search term 'farmers' market' recorded. Between 1985 and 1995, there were only six items that featured the expression 'farmer's market'. We therefore focussed on entries from the subsequent period, for which the growth in media interest is readily apparent (Table 1).

Given that texts were to be analysed qualitatively rather than quantitatively, public notices, duplicate articles, and reports where the Farmers' Market detail was coincidental were removed. This reduced the number of reports to 150 , with a total of about 60,000 words. These reports were held as .txt files for exploration in a text handling programme called Wordsmith $^{\mathrm{TM}}$. Wordsmith uses wordlists and concordances that facilitate content analysis by allowing indexed texts to be selected and read on the screen.

In the analysis each text was read many times, and key words or terms from the academic literature (such as 'food miles', 'short supply chains' and 'organic production') were noted. Wordsmith allowed searches of the database to locate the use of particular words or terms (or their near matches), and analysis of the context in which they were used. The frequency of the use of the word or term across the entire database was also noted. The analytical process allowed the linkage and amplification of themes associated with the questions noted above, to the point where we were confident we understood the place and function of the article in the broader discourse associated with Farmers' Markets. In the following discussion, database item numbers are reported, and a list of the 43 articles cited in the text is included at the end of the paper. Our 
work is informed by the larger database, with the extracted texts used as anchor points for our commentary.

\section{Media representations of the production landscape}

The media reports contain only a few direct references to support for local producers. One article quotes Green Party leader Jeanette Fitzsimons: 'When you buy your lettuce from a farmers' market... you're supporting that farmer in a way of life that's more sustainable, more environmentally friendly and it gives him or her a livelihood and that's important' (146). Another reports Alan Cameron (Massey University) as saying that 'other trends influencing markets' stability were healthy eating campaigns ... and the desire to support local communities' (103). However, support for local producers is more often implied in other considerations, such as reducing 'food miles' (the cost associated with transporting food from site of production to site of consumption): 'It's also about food miles, says Duncan (Manager, Nelson Market), explaining the slow food ideals of eating locally-grown produce instead of using up fossil fuels to transport food around the world and eat it out of season' (1). Timaru market co-ordinator Charissa Newton is reported as emphasising the benefit of capturing the local food dollar: 'Every $\$ 10$ spent at a supermarket generates $\$ 17$ in the local economy. The same amount spent at a farmers market generates $\$ 32$ ' (65). The importance of capturing the 'local food dollar' and using this as an investment base in further local production was not, however, an explicit part of the media discourse.

The support for the 'local' was much clearer in the reportage of the creation of locally branded foods. Markets in Kerikeri, Hastings, Blenheim and Cromwell are among those identified as examples $(133,73)$. The surrounding regions have a history of horticulture and market gardening on which distinctive Farmers' Market production has been based, although only a few (like Hastings and Marlborough) have captured national attention in their promotion of regional food production for Farmers' Markets (78). In terms of benefits, Graeme Avery, who created the 'Hawke's Bay Wine Country' brand, is reported as saying:

Fifty new jobs were created in the first 12 months of the Food Group's formation ... Then followed the establishment of many new artisan businesses that for the first time had a ready route to market for their fledgling business, plus the unique opportunity to test consumer reaction to their products at the farmer's markets. Some have since outgrown the market and gone on to national and even export development (133).

The entrepreneurial nature of production for Farmers' Markets is also acknowledged in the media coverage. In contrast to the comparative uniformity of industrial agriculture in New Zealand, reporters suggest that Farmers' Markets support a wide variety of rural producers who have a range of motivations, and who are in different stages of development. For example, there are some producers who are using Farmers' Markets as an incubator for potential national and international distribution plans $(27,35,106)$, others who target local restaurants (31) and the majority who are either engaged in extending their 'farm gate' sales (100) or marketing quality added-value products from kitchen industry (40). Alan Cameron is reported as emphasising that: '. . . farmers' markets should never be thought of as boutique operations. They are not about nostalgia...they are not a version of the Laura Ashley shops that appeared in Britain. It is business; these people are entrepreneurs' (33). In addition to the 'business incubator' function, reference is made in several reports to the preservation of distinctive varieties that are produced in small volume (by small producers) that would not meet the volume thresholds set by (wholesale distributors) Turners and Growers in 2001. Produce available at Farmers' Markets described as 'heirloom' $(13,101)$, 'traditional' (125), 'rare breed' (25) or 'non commercial' $(33,67)$ highlights the contrast with productivist agriculture. In supporting small local producers, Farmers' Markets are seen as promoting a more diversified agricultural sector. In the words of Jane Adams, the chair of the Australian Farmers' Markets Association: 'Marlborough's proposed farmers' market would help stop the province sliding into a monoculture and being known solely for its wines' (97).

Media reports consistently valorise production for Farmers' Markets, with references to the distinctive processes and outcomes. The report on livestock farmer, Hilton Verry, reveals the economic incentive to produce and supply quality food into a local site of exchange. The Verrys:

... realized that if the farm was going to support them they would have to do more than 
just supply beef to the meat companies. ... They decided to sell at the farmers' market ... but . . . the key to their success lay in replicating the high taste standard found in farm-killed meat. The secret . . . was in reducing stress in the animals about to be killed and in ageing the meat.... The search for stressfree slaughter posed a ... challenge, as there was no abattoir in Hawke's Bay. But the Verrys feel they have done the best they can ... by hiring the whole truck to send cattle there 10 at a time. That means no diversions and no mixing with other people's cattle (117).

In terms of quality, 'organic' (as distinct from local) is frequently cited as a characteristic of food produced for Farmers' Markets. Indeed, 39 reports (or about a quarter of the total) use the term. It is important, however, to look beyond the superficial use of the referent, and to see how substantively the media describe and analyse the contribution of organic production. Commentaries from only four places (Wairarapa 47, Taranaki 54/55, Marlborough 62 and Auckland 84) make more than passing reference to organic produce, with only two offering any real insight into organic production. The report on Lyndsay McGarry's 20-year history of organic production in Riverton (Southland) emphasises the constant striving for quality through organic production. In the words of Mr. McGarry: 'We always have about 100 experiments going on at any one time. You're always learning when you're growing' (131). It seems that the term 'organic' is a convenient quality label for Farmers' Markets to use in their definition of alterity, and that this term is used in the media reportage without much commitment to comment on organic production practices.

\section{Media representations of the consumption landscape}

Challenges to industrial food and the oppositional championing of the quality of 'local food' have often been associated with the valorisation of food itself. The term 'foodie' first appeared in significant print form in The Official Foodie Handbook (Barr and Levy, 1984), and culinary consumption of fresh, high quality, varietal foods has been seen in the promotional branding of 'local foods' and of Farmers' Markets over the intervening years. One of the clearest oppositional themes in the media reports of Farmers' Markets is expressed in terms of approval of the 'slow food movement' and its use of local (read 'quality') produce. The oppositional claims extend to notions of quality of life where 'meaningful' exchanges are considered to take place in Farmers' Markets in contrast to the impersonality of the supermarket $(37,102,146)$. With reference to the consumption of quality, local, and varietal specialities, Kate Monahan (of the Waikato Times) is reported as saying that: 'Slow food is enjoying the sharp flavours of time-crafted parmigiano reggiano cheese on homemade bread, freshly shucked Bluff oysters washed down with local wine, crisp seasonal apples from a local orchard, picked up from a farmers' market' (135).

The extent to which restaurateurs and (celebrity) chefs are cited as Farmers' Market customers in media reports is notable and, in some cases, they are reported to play a role in the organisation and promotion of local Farmers' Markets $(106,147)$. A number of these chefs emphasise developing regional cuisines (102, 119, 124 and 135), with Alan Cameron reported as saying that: 'Farmers' markets are not about factory food. It's all about small amounts of high-value produce, made with love, passion about the things they have ... The thing we're trying to do too is develop a regional cuisine and we're starting to get better at it' (102).

In one report (103) it is argued that provisioning' (customers doing part of their regular weekly shopping) at a Farmers' Market is the key to building a sustainable market and, in the media coverage, many vendors report 'regular' customers $(29,102,108)$. However, it is also clear that markets are treated as 'festival locations' attracting a significant proportion of tourists (70, 120). Tourists may be attracted by the novelty of markets or, as Hamilton Farmers' Market founder, Tracey Lowndes, suggests, to its echoing of an idyllic past: 'There's a nice sense of nostalgia about markets... of wandering the stalls with a wicker basket, living life at a slower pace' (2). Farmers' Markets generally operate during the weekend, when consumers are more likely to have at their disposal the time to invest in 'a cultural experience'. Thus, visitors to Farmers' Markets consume the ambiance of the market as well as the produce on offer. This is evoked in the words of Carol Duncan, manager of the Nelson market, who reports that: 'the mood of the Sunday market is about slow food, slow lifestyle, slow shopping and socialising also part of the philosophy behind farmers' 
markets' (1). Few consumers are reported as making the links to producers the way Jeanette Fitzsimons does:

By demanding ever cheaper food . . . consumers are rendering farmers unable to manage their land in a sustainable way. I don't think we place enough value as a society on buying quality food and food that's grown with concern for the environment. So what can you do? Well, you can shop at farmers' markets for starters (146).

\section{Media representations of Farmers' Markets as sites of exchange}

A range in the number of weekly sellers at Farmers' Markets is reported in the media. Markets in smaller centres, such as Timaru, Feilding, Cromwell and Tokoroa, in early development phases or in the winter months, have been reported with stall-holder numbers as low as nine. The need to build up a producer base was noted in an article reporting on the Timaru market:

... the co-ordinator, Charissa Newton, said the market aimed to help strengthen South Canterbury's bio-business sector by establishing a market where local producers could sell, and both local and visitors could buy, fresh and healthy produce. She hopes to have at least 10 stalls operating this Saturday. As word spreads she hopes more stall holders will join for the weekly market (65).

Longer-established markets, often drawing on regional populations in places like Whangarei, Invercargill, Lyttelton and Nelson (Richmond), are reported as having seasonal highs of around 25 stall holders. Overall, the media reports suggest that at least twelve Farmers' Markets would have been in this 'established' class in 2007. With reference to regular weekly markets, Hastings and Marlborough clearly share the leadership: 'The Hastings market ... is one of the biggest in the country. In summer - when it moves outside - there will be more than 50 stalls' (108). And in Marlborough: 'Stall numbers can rise from 30 to 45 in summer once pip-fruit and stone-fruit comes in season' (106). Descriptions of less regular markets are also included in media accounts.

Markets are further differentiated by their ownership and management style. Most are operated by trust organizations, but the media report exceptions that emphasise the range of experi- ence captured within Farmers' Markets as sites of exchange. Matakana is possibly the best example:

... unlike other markets it is privately owned, but its owners say that is what has made it so popular. There are strict rules around presentation, plastic is banned and all food is presented immaculately. Its boutique style - it is decked out like a small village with wooden stalls and a live band - is key to its appeal ... (37).

Farmers' Markets need to attract customers and the variety of consumers is noted in the media accounts. Reports of numbers further differentiate markets; some report 'attracting 3000 to 5000 people each week' (117), but it seems that a customer base in excess of 1000 should be expected in only the largest markets (31). According to the media, an almost uniform set of experiences await visitors to Farmers' Markets. This expectation is based on one almost universally accepted principle of Farmers' Markets, namely that they are places where producers and consumers engage in discourse about produce. As Charissa Newton (market co-ordinator, Timaru) is reported as saying: 'The grower is able to gain direct contact with the consumer so that they may estimate purchase trends, get feedback, and discuss requests' (65). In the words of Pauline Vari, market manager at the Founders' Market in Nelson, 'Because the producers themselves are on-site, customers can interact with them personally... They can discuss anything from ways to use the produce, to what to look out for in coming weeks. It is a wonderful concept' (147). The Farmers' Market 'branding' makes much of the terms 'local' and 'authenticity', with authenticity very much a characteristic of the exchange. In the words of Lania Pohio, a honey producer in the Hamilton market: 'The key word is authenticity. People can ask questions and know where the product comes from' (113).

What is less normative, in our view, are the descriptors used in the media coverage; While terms like 'colourful', 'vibrant' and 'festival' were commonly used for these sites of exchange, the word that appeared most frequently was 'entertainment' (7, 102, 146). Reporter Glynn Christian's account of the Whangarei Farmers' Market describes the market as a site of social exchange:

Best of all, I sometimes had to wait because stallholders and customers alike were 
gossiping, exchanging recipes, showing pictures of new grandchildren, even making hot dates. Just imagine going somewhere like that to shop once or twice a week, chatting to and buying from trusted friends. How good would that be? (84).

Farmers' Markets may be sites of produce and conversational exchange, but they operate in a manner that embeds this exchange in a social context.

\section{Discussion and conclusions}

'... the media coverage which Farmers' Markets have received... has invested them with a certain fashionability ...' (Holloway and Kneafsey, 2000, 292)

Producers meet consumers to trade goods at locations constituted as Farmers' Markets for several hours a week on a regular basis. This somewhat ephemeral activity of exchange is 'constructed' as a local phenomenon of systemic significance in both the international research literature and the New Zealand media. In our exploration of the Farmers' Market phenomenon we moved back and forward between these two sets of commentaries, letting each reveal what is seen and unseen by each set of commentators, recognising that they have different readerships, but with the expectation that similar themes would emerge in each discourse. In our concluding comment, we return to the questions posed early in the paper concerning the production, consumption and exchange characteristics of Farmers' Markets, and note the distinctive ways of seeing Farmers' Markets in the media and in academic discourses.

With respect to production, we note in the media reports evidence of geographical variation in the capacity of localities to supply Farmers' Markets and in the way that production for Farmers' Markets features within (often regional) agricultural systems. This is a cue to reflect on the oppositional (to productivist agriculture) positioning of Farmers' Markets theorised in the academic literature. We find the media reports to be dominated by individual production stories in which quality food and distinctiveness issues are central, especially in the promotion of regionally based produce like fruit and wine, but in which the alterity of production is not systematically noted. The academic literature valorises local production for Farmers' Markets through reference to food miles, capture of the local food dollar and co-development prospects for local (rural) communities. The media treatment is not silent on these issues, but they are hidden in text and seldom feature prominently in the accounts of producer activities. The case of organic production is different: the media accounts frequently use 'organic' as an identifier of alterity in Farmers' Markets, and often do so as an appendage or elaboration of 'local', but very rarely do they report or explain the production requirements. Organic is not a strong theme in the New Zealand media content analysed.

Consumption dominates the media reportage of Farmers' Markets (as it does the academic literature), and this is largely driven by the nature of the media itself; the bulk of its readership being consumers rather than other (producer or manager) actors in Farmers' Markets. Regional newspapers like the Marlborough Express, Waikato Times and Southland Times feature in the sources listed in the media reference list, and their focus on (and positive reportage of) local consumption is obvious, if uncritical. For example, with reference to consumers, not one report explores the issues of race and class exclusion that are immediately apparent in any visit to New Zealand Farmers' Markets. The links between local (quality) produce, 'slow' food and regionally-distinctive cuisine dominated the media reportage, although nostalgia for simpler times was also present as a sub-text. There were few references to the characteristics of reflexive consumption theorised in the academic literature - through which consumers choose to buy certain foods (e.g., organic) in particular places (e.g., in Farmers' Markets instead of supermarkets). Instead, as predicted by some academic commentators, there are consistent references to the 'consumption' of the Farmers' Market experience, and this occurred to such an extent that we wonder whether some markets (dominated by those seeking entertainment rather than local food) might be better thought of as 'market festivals' rather than Farmers' Markets.

With respect to markets as sites of exchange for rural produce, the media coverage says little of significance about the number and nature of local producers, as this relates either to the market experience or to sustainability. Instead, the primary emphasis in the media coverage is on the benefits of face-to-face contact between producer and consumer offered at this site of exchange, which echoes observations in the academic literature concerning the importance of 
social relations at Farmers' Markets. Few media reports look closely at the vendor and customer bases that will be required to make Farmers' Markets a sustainable part of the local economic fabric, and none argue for their theorised role in promoting the co-development of agriculture and the broader community.

Standing back from the complementary ways of seeing Farmers' Markets, we ask two questions; how does the reportage of Farmers' Markets in New Zealand relate to international research and what new insights can be drawn from the way Farmers' Markets are seen in the New Zealand media? On the first issue we suggest that there are a number of significant and important ideas in the academic literature that are not reported. In the realm of production, an awareness of alternatives in (contested) productivist space is low and the sustainability of traditional regimes of production is not questioned. In the realm of consumption, few media reporters explore ideas of reflexive consumption, and the continued expansion of the customer base for Farmers' Markets is assumed uncritically. Given the recency of the growth in Farmers' Market numbers and the local/regional emphasis of the media coverage, such 'naivety' is understandable. Looking forward, we would expect to see much more systematic uptake of themes such as diversity in local economic development, quality issues in local food, and food miles. Indeed, 'food miles' is emerging as a major issue in the international media (www.bbc.co.uk/food/ food_matters/foodmiles.shtml) and its relevance to local food production and consumption is currently very topical.

On the second issue, we would argue that media reports should not be seen as peripheral to our understanding of the recent (re)emergence of Farmers' Markets as sites of exchange. Collectively, these reports have an immediacy and a localness that is vital to our appreciation of what is happening 'in the field' and 'at the market'. Beneath the superficial nature of much of the coverage of Farmers' Markets in New Zealand, our analysis revealed the efforts of some reporters (often with several years of commentary in the local and interest area) to link day-to-day experience with debates about major environmental, economic and social issues. While less inclined than the academic literature to see the interconnectedness of change in systems of production, consumption and exchange, the media coverage reminds us that there is a limit to theorisation - much about Farmers' Markets may be transitory and moulded locally, and should be valued as such.

\section{REFERENCES}

Allen, P., Fitzsimmons, M., Goodman, M. and Warner, K., 2003: Shifting plates in the agri-food landscape: the tectonics of alternative agri-food initiatives in California. Journal of Rural Studies 19, 61-75.

Andreatta, S. and Wickliffe, W., 2002: Managing farmer and consumer expectations: a study of a North Carolina farmers' market. Human Organization 61, 167-176.

Argent, N., 2002: From pillar to post? In search of the postproductivist countryside in Australia. Australian Geographer 33, 97-114.

Armitage, D.G., 2001: Ontario farmers' commitment to the natural environment: a report to the Walkerton Commission. Ontario Farm Environmental Coalition, Guelph.

Australian Farmers' Markets Association/Farmers' Markets New Zealand, 2007: Guide to Farmers' Markets: New Zealand and Australia. R.M. Williams Classic Productions, Mosman, Australia.

Barr, A. and Levy, P., 1984: The Official Foodie Handbook. Timbre Books, New York.

Bell, D., 2006: Variations on the rural idyll. In Cloke, P., Marsden, T. and Mooney, P. (eds) Handbook of Rural Studies. Sage Publications, London, 149-160.

Connell, D., Smithers, J. and Joseph, A. E., 2008: Farmers' markets and the good food value chain: A preliminary study. Local Environment 13, 169-185.

Coster, M., 2004: Report on the Role of 'New Generation' Farmers' Markets. Department of Primary Industries, Bendigo, Australia.

Feagan, R., Morris, D. and Krug, K., 2004: Niagara Region Farmers' Markets: local food systems and sustainability considerations. Local Environment 9, 235-254.

Goodman, D., 2002: Rethinking production-consumption: integrative perspectives. Sociologia Ruralis 42, 271-277.

Goodman, D., 2003: The quality 'turn' and alternative food practices: reflections and agenda. Journal of Rural Studies $19,1-7$.

Goodman, D. and DuPuis, E., 2002: Knowing food and growing food: beyond the production-consumption debate in the sociology of agriculture. Sociologia Ruralis 42, $5-22$.

Guthrie, J., Guthrie, A., Lawson, R. and Cameron, A., 2006: Farmers' markets: the small business counter-revolution in food production and retailing. British Food Journal 108, 560-573.

Hinrichs, C., 2000: Embeddedness and local food systems: notes on two types of direct agricultural market. Journal of Rural Studies 16, 295-303.

Hinrichs, C., 2003: The practice and politics of food system localization. Journal of Rural Studies 19, 33-45.

Hinrichs, C., Gillespie, G. and Feenstra, G., 2004: Social learning and innovation at retail farmers' markets. Rural Sociology 69, 31-58.

Holloway, L. and Kneafsey, M., 2000: Reading the space of the farmers' market: a case study from the United Kingdom. Sociologia Ruralis 40, 285-299.

Ilbery, B. and Kneafsey, M., 2000: Producer constructions of quality in regional speciality food production: a case study from southwest England. Journal of Rural Studies 16, 217-230.

Ilbery, B. and Maye, D., 2005: Alternative or conventional? An examination of specialist livestock production systems in the Scottish-English borders. In Essex, S., Gilg, A., 
Yarwood, R., Smithers, J. and Wilson, R. (eds) Rural Change and Sustainability: Agriculture, the Environment, and Communities. C.A.B. International, Oxfordshire, 95-106.

Joseph, A., Lidgard, J. and Bedford, R., 2001: Dealing with ambiguity: on the interdependence of change in agriculture and rural communities. New Zealand Geographer 57, $16-26$.

Kirwan, J., 2004: Alternative strategies in the UK agro-food system: interrogating the alterity of farmers' markets. Sociologia Ruralis 44, 395-415.

Kneafsey, M. and Ilbery, B., 2001: Regional images and the promotion of specialty food and drink in the West Country. Geography 86, 131-140.

McEachern, M.J. and Willock, J., 2004: Producers and consumers of organic meat: a focus on attitudes and motivations. British Food Journal 106, 534-552.

McMichael, P., 2000: The power of food. Agriculture and Human Values 17, 21-33.

Miele, M., 2006: Consumption culture: the case of food. In Cloke, P., Marsden, T. and Mooney, P. (eds) Handbook of Rural Studies. Sage Publications, London, 344-354.

Rigby, D. and Caceres, D., 2001: Organic farming and the sustainability of agricultural systems. Agricultural Systems $68,21-40$.

Seymore, E.J. and Ridley, A.M., 2005: Toward environmental management systems in Australian agriculture to achieve better environmental outcomes at the catchment scale. Environmental Management 35, 311-329.

Smithers, J., Joseph, A. E. and Armstrong, M., 2005: Across the divide (?): reconciling farm and town views of agriculture-community linkages. Journal of Rural Studies 21, 281-295.

Warner, K., 2007: The quality of sustainability: agroecological partnerships and the geographic branding of California wine grapes. Journal of Rural Studies 23, 142-155.

Weatherell, C., Tregear, A. and Allinson, J., 2003: In search of the concerned consumer: UK public perceptions of food, farming and buying local. Journal of Rural Studies 19, 233-244.

Winter, M., 2003: Embeddedness, the new food economy and defensive localism. Journal of Rural Studies 19, 23-32.

\section{Media references cited in text}

Note: Numbering of media references is specific to the full (150-item) database.

1. Peddle Power. THE NELSON MAIL, 8 Nov 2005 , Edition 2, Page 11.

2. Farmers' market grows like topsy. WAIKATO TIMES, 8 Nov 2005, Edition 2, Page 7.

13. Golden harvest to spice up port. THE PRESS, 3 Sep 2005, Edition 2, Page 13.

25. Farmers' market to start this Sunday. THE DAILY NEWS, 9 Jun 2005, Edition 1, Page 17.

27. Time to get cracking. THE SOUTHLAND TIMES, 17 Aug 2002, Edition 1, Page 32.

29. Lemons popular at market. THE MARLBOROUGH EXPRESS, 11 May 2005.

31. To market, to market. THE DOMINION POST, 5 May 2005, Edition 2, Page 7.

33. Off to market. EVENING STANDARD, 3 May 2005, Edition 1, Page 11.

35. Nut pioneers set to reap. THE SOUTHLAND TIMES, 29 Mar 2005.

37. Growing community at farmers' markets. SUNDAY STAR TIMES, 20 Feb 2005, Edition A, Page 17.
39. Farmers' market delays until spring. THE NELSON MAIL, 9 Feb 2005, Edition 2, Page 4.

40. Get really fresh at market. THE DOMINION POST, 4 Feb 2005, Edition 2, Page 3 .

41. Bigger festival. THE PRESS, 4 Feb 2005, Edition 2, Page 4.

47. Organic foods a growth industry. THE DOMINION POST, 25 Nov 2004, Edition 2, Page 7.

54. Growers to form organic food market in Taranaki. THE DAILY NEWS, 4 Oct 2004, Edition 1, Page 4.

55. Farmers' market set to go. THE BAY CHRONICLE, 1 Oct 2004.

62. Personal touch key to success. THE MARLBOROUGH EXPRESS, 23 Apr 2004.

65. New shopping trend. THE TIMARU HERALD, 8 Apr 2004, Edition 2, Page 13.

67. Market brings good of the country to town. THE DOMINION POST, 19 Jan 2004, Edition 1, Page 7.

70. Holidaymakers provide unexpected success. THE MARLBOROUGH EXPRESS, 29 Dec 2003.

71. Direct sales tack pays off. THE TIMARU HERALD, 15 Nov 2003, Edition 2, Page 17.

73. Old Cromwell Town to get farmers' market. THE SOUTHLAND TIMES, 24 Oct 2003, Edition 1, Page 19.

78. Working to make Hawke's Bay hotter. THE DOMINION POST, 23 Apr 2003, Edition 2, Page 10.

80. Strangled by vines? THE MARLBOROUGH EXPRESS, 10 Oct 2002.

84. Stall story. NEW ZEALAND HERALD, 8 Jun 2002.

97. Enthusiasm grows for farmers' market in Marlborough THE MARLBOROUGH EXPRESS, 15 Jun 2001

100. Follow that brochure. DOMINION, 5 Dec 2000, Edition 2, Page 16

101. Farmers' Markets. THE PRESS, 16 Nov 2006, Edition 2, Page 1.

102. Market making mark. MANAWATU STANDARD, 20 Jun 2006, Page 13

103. Farmers' markets build businesses. THE NATIONAL BUSINESS REVIEW, 23 Jun 2006, 29-01

106. Farmers' markets are taking off. RURAL NEWS, 2 Aug 2006.

108. All the fun of the fare. THE DOMINION POST, 8 Jul 2006, Edition 2, Page 4

113. Buzz about markets. WAIKATO TIMES, 28 Jun 2006 Page 2.

117. Taste triumphs at the market. MANAWATU STANDARD, 13 Jun 2006, Edition 2, Page 13.

119. Farmers' market NZ holds its inaugural conference in Havelock North. RADIO NEW ZEALAND NEWSWIRE, 16 Jun 2006.

120. Wares snapped up at farmers' market. THE DOMINION POST, 5 Dec 2006, Page 7.

124. More farmers' markets sprout up. THE DOMINION POST, 13 Jul 2006, Page 5.

125. Personal touch valued. WAIKATO TIMES, 28 Jun 2006, Page 2.

131. Organic video star opens farmers' market in Riverton THE SOUTHLAND TIMES, 4 Apr 2006, Edition 1, Page 16

133. Mr Farmers Market. RURAL NEWS, 27 Jun 2006.

135. Easing up the pace of life. WAIKATO TIMES, 28 Jun 2006, Edition 2, Page 4.

146. Market forces. SUNDAY STAR TIMES, 14 Jan 2007, Page 3.

147. Joining a market revolution. THE NELSON MAIL, 23 Jan 2007, Page 11. 